\title{
Seasonal dynamics of occurrence and group size of three species of cetaceans (Delphinidae and Phocoenidae) on the southwestern coast of the Black Sea
}

\author{
Nastassia Uluduz, Alexey Yanchukov, Mustafa Sözen \\ Zonguldak Bulent Ecevit University, Faculty of Arts and Science, Department of Biology, Laboratory of Molecular \\ Systematics, 67100 İncivez/Zonguldak, Turkey. \\ (NU) (Corresponding author) E-mail: nastassia.uluduz@ gmail.com. ORCID iD https://orcid.org/0000-0002-7366-0267 \\ (AY) E-mail: yawa33@gmail.com. ORCID iD https://orcid.org/0000-0002-9613-8770 \\ (MS) E-mail: spalaxtr@hotmail.com. ORCID iD https://orcid.org/0000-0002-1911-605X
}

\begin{abstract}
Summary: The spatial and temporal occurrence of cetaceans in the Black Sea and particularly along its southwestern coastline is poorly studied. Based on a total of 609 encounters, we present the analysis of monthly dynamics of (1) the numbers of cetacean sightings and (2) their group size for all three Black Sea cetacean species: the bottlenose dolphin (Tursiops truncatus), the short-beaked common dolphin (Delphinus delphis) and the harbour porpoise (Phocoena phocoena) over a continuous period of 29 months (January 2018 - May 2020) from two fixed coastal observation points near the city of Zonguldak, Turkey. Seasonal fluctuations were found in the occurrence of all three species, with peaks in April-May (spring). Similarly, the largest groups of $P$. phocoena and T. truncatus were recorded in the late spring and early summer period, while D. delphis had a peak in July (summer). In case of the harbour porpoise, we speculate that these variations can be explained by the annual migrations from the northwestern to southern waters of the Black Sea, while the seasonal dynamics of the two Delphinidae species might depend on fish prey availability. While our data were collected locally, the results provide better insight into the ecology of cetaceans within the entire Black Sea.
\end{abstract}

Keywords: Black Sea; common dolphin; bottlenose dolphin; harbour porpoise; seasonal dynamics; time series; group size.

Dinámica estacional de ocurrencia y tamaño de grupo de tres especies de cetáceos (Delphinidae y Phocoenidae) en la costa suroeste del mar Negro

Resumen: La presencia espacial y temporal de cetáceos en el mar Negro, particularmente a lo largo de su costa suroeste, está poco estudiada. Con base en un total de 609 encuentros, presentamos el análisis de la dinámica mensual de (1) el número de avistamientos de cetáceos y (2) el tamaño del respectivo grupo, para las tres especies de cetáceos del mar Negro: el delfín mular (Tursiops truncatus), el delfín común (Delphinus delphis) y la marsopa común (Phocoena phocoena), durante un período continuo de 29 meses (entre enero de 2018 y mayo de 2020) desde dos puntos de observación costeros fijos cerca de la ciudad de Zonguldak, Turquía. Se encontraron fluctuaciones estacionales en la ocurrencia de las tres especies, con picos en abril-mayo (primavera). Los grupos más grandes de $P$. phocoena y $T$. truncatus se registraron a fines de la primavera y principios del verano, mientras que los de $D$. delphis tuvieron un pico en julio (verano). En el caso de las marsopas comunes, especulamos que estas variaciones pueden explicarse por las migraciones anuales desde las aguas del noroeste al sur del Mar Negro, mientras que la dinámica estacional de las dos especies de Delphinidae podría depender de la disponibilidad de peces para captura. Si bien nuestros datos se recopilaron localmente, los resultados brindan una mejor comprensión de la ecología de los cetáceos en todo el mar Negro.

Palabras clave: mar Negro; delfín común; delfín mular; marsopa común; dinámica estacional; series de tiempo; tamaño del grupo.

Citation/Como citar este artículo: Uluduz N., Yanchukov A., Sözen M. 2020. Seasonal dynamics of occurrence and group size of three species of cetaceans (Delphinidae and Phocoenidae) on the southwestern coast of the Black Sea. Sci. Mar. 84(4): 431-439. https://doi.org/10.3989/scimar.05086.21A

Editor: D. Oro

Received: May 26, 2020. Accepted: September 4, 2020. Published: October 8, 2020.

Copyright: $\odot 2020$ CSIC. This is an open-access article distributed under the terms of the Creative Commons Attribution 4.0 International (CC BY 4.0) License. 


\section{INTRODUCTION}

The Black Sea is home to three cetacean species with global distribution: the bottlenose dolphin (Tursiops truncatus), the short-beaked common dolphin (Delphinus delphis) and the harbour porpoise (Phocoena phocoena). They are found in the entire Black Sea and the neighbouring Sea of Azov, the Kerch Strait and the Turkish Strait System (BSC 2008) and are thought to have colonized the region in the Late Pleistocene (Viaud-Martinez et al. 2007, 2008, Tonay et al. 2020). The Black Sea is an ecosystem heavily transformed by human activity presently and in the past. Despite the cease of the commercial targeting of dolphins in the 1950s, accidental by-catch remains one of the main conservation threats (Tonay and Öztürk 2012). The simultaneous use of the waters by cetaceans and humans leads to disruption of dolphin habitats and their behaviour due to the effect of such factors as oil pollution, loss of habitats and food resources (BSC 2008). In order to assess the impact of anthropogenic disturbance, it is important to know the occurrence and seasonal changes in habitat use by cetaceans.

The information on cetacean occurrence, distribution and abundance in the Black Sea is often obtained from non-regular observations during tourist cruises and opportunistic sightings (Gladilina et al. 2013, Panayotova and Todorova 2015b) or stranding surveys (Vishnyakova and Gol'din 2015). There is a clear knowledge gap in our understanding of seasonal changes of occurrence of small cetaceans of the Black Sea. The few studies with some data on the monthly occurrence dynamics were conducted by Gladilina (2012) on the Northern Black Sea coastline and by Baş et al. (2019), Paiu et al. (2019b) in the Istanbul Strait and the western Black Sea, respectively. Little is known about the seasonal dynamics of cetaceans in the southwestern part of the Black Sea.

Previous studies suggested that the distribution, movement and presence of the Black Sea cetaceans often depend on the migration patterns of the fish prey species (Dede and Tonay 2010, Panayotova and Todorova 2015a). The bottlenose dolphin in the Black Sea is known to inhabit shallow areas with warm water but is sometimes seen far from the shore (Mikhalev 2005a, Ryakov and Panayotova 2012, Birkun et al. 2014). These patterns might be related to feeding preferences for pelagic and benthic fish species (Gladilina and Gol'din 2014). The short-beaked common dolphin occurs from the shore waters to many kilometres off the coast, but it is mostly observed in the open sea because it feeds on small schooling fishes (Hammond et al. 2008). The harbour porpoise is a typical coastal species that often visits lagoons, inlets, and even rivers (Reeves and Notarbartolo di Sciara 2006, Birkun et al. 2014, Sanchez-Cabanes et al. 2017). There have been cases in which porpoises have gone upstream the Danube up to the city of Izmail and lake Yalpuh in the Odessa region of Ukraine (Birkun 2006). The occurrence and distribution of cetaceans might be related to a local set of environmental conditions that make the presence of cetaceans more likely in certain areas. Previous studies by Gladilina and Gol'din (2016) showed that there is a clear difference in group size and distribution density of the bottlenose dolphin among the coastal areas of the Crimean peninsula. Sea depth, surface temperature and salinity can affect the pattern of occurrence and movements of cetaceans (Marini et al. 2015, Sanchez-Cabanes et al. 2017). The predictive models for the Black Sea cetaceans reveal that depth might be a significant factor that influences their distribution, pointing to a likely association of the common dolphin with greater depths of up to $2250 \mathrm{~m}$, while the bottlenose dolphin and the harbour porpoise prefer the depths of 200-250 $m$ (Sanchez-Cabanes et al. 2017). Surface temperature is another important predictor of occurrence, with the common dolphin preferring colder waters and the other two species preferring warmer waters (Sanchez-Cabanes et al. 2017). It has been reported that the common dolphin avoids the Azov Sea and is generally absent in the Kerch Strait, which has low water salinity (BSC 2008). During acoustic studies in the Istanbul Strait (Dede et al. 2014), it was found that other seemingly minor factors such as the attraction of schools of fishes by illumination from different installations along the coast may in turn attract the cetaceans, as well as alter their behaviour (e.g. from travelling to feeding).

Since the Black Sea coastline encompasses a diverse range of habitats, the pattern of cetacean distribution here may depend strongly on the local factors. The southwestern coastline of the Black Sea features distinct topographic and oceanographic characteristics, such as the presence of saline exchange flow from the Marmara Sea through the Istanbul Strait (Latif et al. 1991, Oğuz 2005), reduced fresh water input due to lack of large rivers (Zaitsev 2008) and a narrower sea shelf than in the northern and northwestern parts of the Black Sea (Tezcan et al. 2017). Seasonality is a very important factor in local occurrence patterns (Gladilina 2012, Baş et al. 2019, Paiu et al. 2019b), but no study to date has included comparable continuous observation data throughout several consecutive seasons in the southern part of the Black Sea.

Our study was set up to reveal the presence of cetaceans in an area where neither land-based nor long-term boat surveys had ever been conducted. The observations spanning the entire annual cycle provide basic information on seasonal dynamics of the cetacean sightings and group size in this region and therefore make an important contribution to marine mammal research in the Black Sea.

\section{MATERIALS AND METHODS}

\section{Study area}

The research area is a part of the southwestern coastline of the Black Sea within the borders of the Zonguldak administrative region, between the towns of Zonguldak and Caycuma (Fig. 1). The coast of the study area is characterized by a narrow continental shelf with a very steep slope that reaches up to $10^{\circ}$ at some points (Ivanov and Belokopytov 2013, Tezcan et al. 2017). 


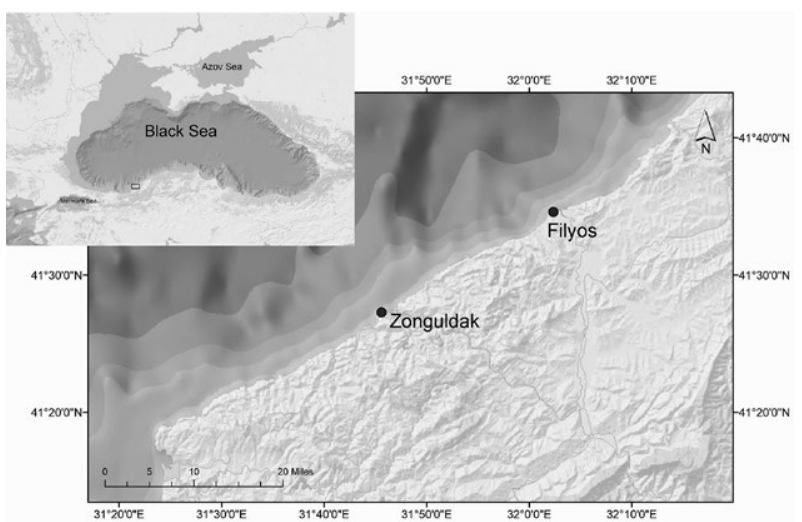

Fig. 1. - Map of the study area with two points chosen for the landbased observations in the Zonguldak administrative region.

For the coastal surveys, we selected two points with the widest view of the aquatory, appropriate height and limited suitability for public access (Rogan et al. 2000). The first observation point $\left(34 \mathrm{~m}, 41.45446^{\circ} \mathrm{N}\right.$, $31.76001^{\circ} \mathrm{E}$ ) was located near the city port of Zonguldak, with moderate marine traffic (Fig. 1). The second observation point $\left(30 \mathrm{~m}, 41.57647^{\circ} \mathrm{N}, 32.03946^{\circ} \mathrm{E}\right)$ was close to the mouth of the Filyos River, forming a wide valley. The shore habitat of this point is a sand beach that is usually free of public recreational use all year around and has only occasional marine traffic.

\section{Collection of data}

Data were collected during regular shore-based observations from January 2018 to May 2020. The majority $(\sim 98 \%)$ of observation sessions were conducted by a single observer (NU). In total, 172 days of coastal observations were carried out following the standard protocol, using binoculars with 10-20 x magnification and a digital photocamera (Canon EOS 660D, lens AF 70-300 mm 1:4-5.6 LD). The on-site recording of sightings was accompanied by photographs and video recordings (when necessary) and therefore allowed for more precise identification of species and objective evaluation of group sizes after the fieldwork. The observation sessions were planned in order to cover equal periods of daylight hours, either in the 07:00-12:00 or 12:00-17:00 time window. We worked in two-hour sessions, divided into periods of 15 minutes. With the exception of four instances (in January and March 2019) when two observation sessions were conducted in a single day, we logged a single session per day. The observations were conducted only under the suitable environmental conditions when visibility was not less than $2 \mathrm{~km}$, sea condition was 0-3 points according to the Beaufort scale, and other conditions posed no difficulties to the observer (Gladilina et al. 2013). The air temperature, the wind direction and the cloud cover were recorded as well.

During each two-hour observation session, we recorded the number of sightings (i.e. visual detection of an individual or a group) as well as group size. A standard definition of a group as a set of animals showing similar behaviour, with the distance between individuals no greater than $100 \mathrm{~m}$ was applied (Genov et al. 2019). This distance was estimated relative to the animal body sizes, visually as well as from the photographs, and in the vast majority of cases was much smaller than $100 \mathrm{~m}$. At the same time, the distances between different, simultaneously observed groups in all three species were visually far greater than $100 \mathrm{~m}$. The sightings of single individuals were recorded as a group of size $=1$. The numbers of adult, juvenile and calf specimens in a group were recorded as well. For the harbour porpoises, only one category of young animals was registered, i.e. calves, because the remaining age categories are difficult to distinguish reliably from the shore.

\section{Data analysis}

All statistical analyses were carried out using $\mathrm{R}$ 3.6.3 software (R Core Team 2020).

We applied the chi-squared test on the numbers of observation days for each of the four seasons and at two observation sites grouped into a $2 \times 4$ contingency table. The test was used to demonstrate that the number of observation days was evenly distributed at two observation sites and did not fluctuate significantly across seasons (Baş et al. 2019). The same test was used to evaluate whether the numbers of observations conducted at both study sites in different periods of daylight were comparable.

Temporal variations in relation to the season (spring, summer, autumn and winter) and daytime were estimated using a non-parametric Kruskal-Wallis test. Several descriptive statistics parameters (standard error of the mean, mean and median) were calculated for each species in respect to the group size and the number of sightings.

The monthly variation of the sighting frequency [SF, the average number of cetaceans sightings in one hour for each month ( $\mathrm{SF}=\mathrm{N}$ _sightings/N_hours)] as well as of the number of individuals per group were analysed as time series. We applied the function decompose() in $\mathrm{R}$ stats package ( $\mathrm{R}$ Core Team 2020) to decompose the time series into respective trend $(\mathrm{T})$, seasonal (S) and error (e) components, based on the additive model $\mathrm{Y}(\mathrm{t})=\mathrm{T}(\mathrm{t})+\mathrm{S}(\mathrm{t})+\mathrm{e}(\mathrm{t})$, where $\mathrm{Y}(\mathrm{t})$ is the observation data at time point $\mathrm{t}$. The trend component was determined as a series of moving averages over six-month periods and subtracted from the data. Next, the seasonal component was estimated as a centred average calculated for each month. Finally, both the trend and the seasonal components were subtracted from the observation data, with the remainder representing an error component. We used a non-parametric Friedman sum rank test (Conover and Iman 1981) as a standalone function in the R stats package and as part of the Prentice test in the muStat package that allows for missing data in 2020 (Wittkowski and Song 2012) in order to estimate the significance of seasonal variation in the time series before and after the trend and error were removed. The Friedman/Prentice test is a non-parametric test based on the comparison of the sums of ranks between paired groups. Before time series decomposi- 
Table 1. - Number of observations and animal sightings during the fieldwork conducted between January 2018 and May 2020.

\begin{tabular}{lcccc}
\hline Month & Season & Number of observation days & Days with sightings recorded & Total number of sightings \\
\hline December & & 7 & 4 & 14 \\
January & Winter & 28 & 19 & 81 \\
February & & 14 & 13 & 110 \\
March & 16 & 14 & 113 \\
April & Spring & 16 & 15 & 78 \\
May & & 10 & 9 & 51 \\
June & 18 & 16 & 33 \\
July & Summer & 16 & 10 & 13 \\
August & & 11 & 4 & 13 \\
September & \multirow{2}{*}{ Autumn } & 17 & 7 & 2 \\
October & & 7 & 1 & 609 \\
November & & 172 & &
\end{tabular}

tion, the comparisons were made between two years for which we had complete monthly data (2018-19). After decomposition, the seasonal component derived from the observation data from 2018-19 and the additional five months of observations in 2020 was projected until the end of 2020. Standard R plotting functions were used to visualize the results.

\section{RESULTS}

We logged a total of 172 days of land-based observations during the entire study period. The presence of cetaceans was recorded on 119 days (69\% of total, Table 1). A total of 609 encounters of three species of cetaceans were recorded in both observation sites. The numbers of surveys between the two observation sites were evenly distributed among all seasons $\left(\mathrm{chi}^{2}\right.$-test $\mathrm{p}=0.79$ ).
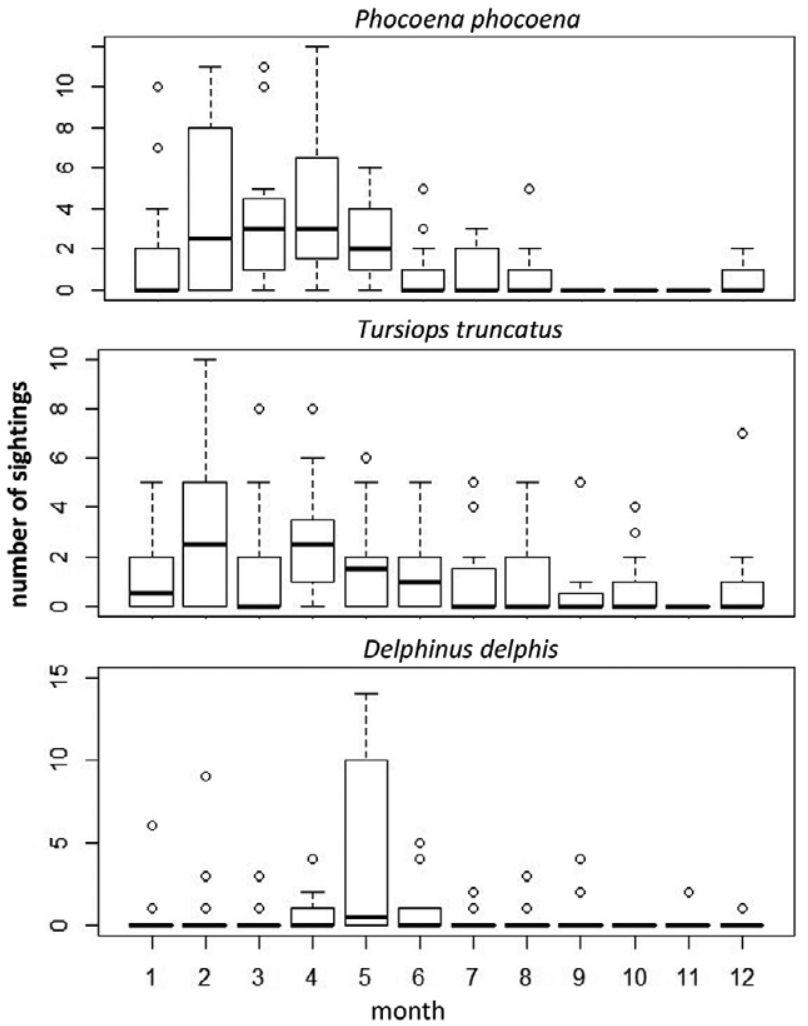

The chi $^{2}$-test also indicated that the number of observations with regard to the time of day at both observation sites was not significantly different across seasons $(p=0.057)$.

The most frequently observed species in the study period was the harbour porpoise (Phocoena phocoena), which was recorded in $45 \%$ of all observation sessions (271 sightings). The sighting dynamics of this species had a clear seasonal pattern (Figs 2 and 4). Porpoises were observed regularly from December to August, with the exception of February 2019, and were absent from September to November (autumn). The maximum number of sightings recorded during one observation day was equal to 12 (Table 2). The peak observation of harbour porpoise was recorded in April $(23 \%)$, with a subsequent decrease in sightings until it reached zero in September. The Kruskal-Wallis test revealed significant fluctuations among the four seasons
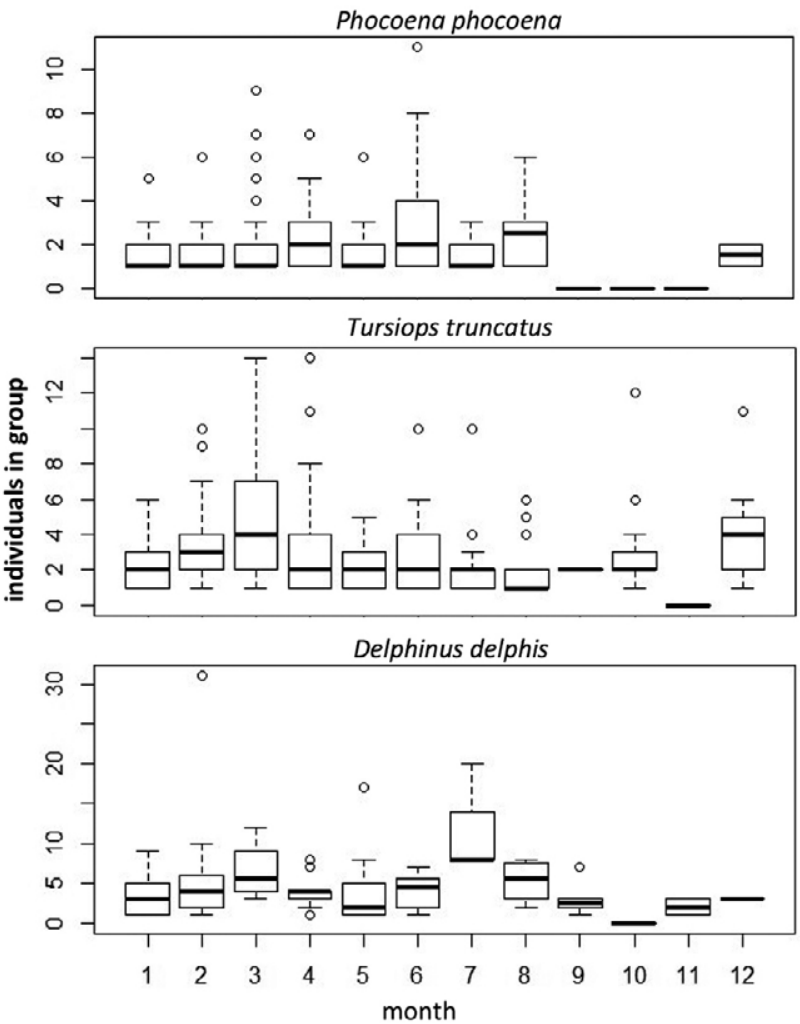

Fig. 2. - Monthly numbers of sightings and group size of the three cetacean species in the study area from January 2018 to May 2020 (the bold line within boxes indicates the median). 
Table 2. - Descriptive statistics of animal sightings and group size for three species of Black sea cetaceans. n, sample size; max, maximum number of sightings in one observation day/specimens in one group; SEM, standard error of the mean.

\begin{tabular}{|c|c|c|c|c|c|c|c|c|c|}
\hline \multirow{2}{*}{ Species } & \multirow[b]{2}{*}{$\mathrm{n}$} & \multicolumn{4}{|c|}{ Sighting } & \multicolumn{4}{|c|}{ Group size } \\
\hline & & $\max$ & mean & median & SEM & $\max$ & mean & median & SEM \\
\hline Bottlenose dolphin & 234 & 10 & 2.9 & 2 & 0.25 & 14 & 3.1 & 2 & 0.17 \\
\hline Harbour porpoise & 271 & 12 & 3.7 & 2 & 0.40 & 11 & 1.9 & 1 & 0.09 \\
\hline Common dolphin & 104 & 14 & 3.3 & 2 & 0.63 & 31 & 4.4 & 3 & 0.40 \\
\hline
\end{tabular}

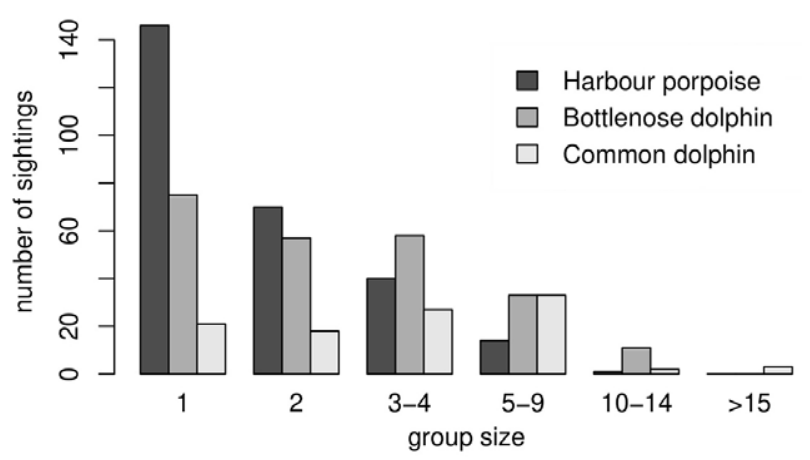

Fig. 3. - Group size of three cetacean species in the study area observed from January 2018 to May 2020.

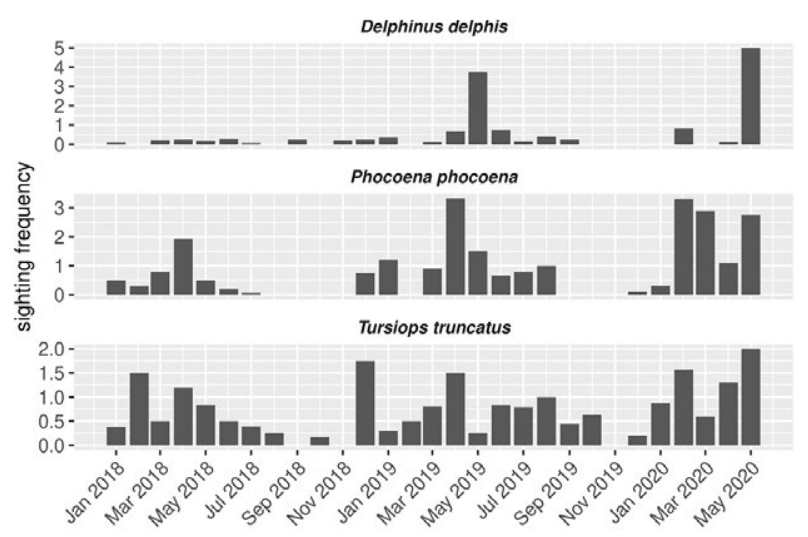

Fig. 4. - Dynamics of sighting frequency for three cetacean species observed in the study area from January 2018 to May 2020.

(test statistic $=31.39, \mathrm{df}=3, \mathrm{p}<0.01$ ), but no significant variation with respect to daytime $(\mathrm{p}=0.88)$. The calves were observed 11 times during the entire study period, in February-May and in August (Table 3). The harbour porpoise preferred to stay at the distance of 200-300 $\mathrm{m}$ from the shore. The minimum mean group size was 1.4 (July) with the median $=1$, and the maximum mean group size was recorded in June (3.2) with the median=2 (Fig. 2). Of all sightings, 54\% were attributed to individual animals (Fig. 3). The maximum number of porpoises in a single group was observed in June (11 specimens, Table 2). The year average group size was $1.9 ;$ median $=1$.
The second most sighted dolphin species was the bottlenose dolphin (Tursiops truncatus), which was encountered in 234 sightings (38\%). These animals occurred in the study area all year around (Fig. 4). The majority of sightings were in spring (35\%), while the lowest number of sightings was recorded in autumn (9\%, Fig. 2). A Kruskal-Wallis test showed the difference in the number of sightings to be marginally significant among the seasons $(\mathrm{p}=0.041)$, and this value did not fluctuate significantly in regard to time of day $(\mathrm{p}=0.08)$. Adult animals were accompanied by calves in March-June (10 sightings), with a peak in April, while juveniles were observed all year around: in March one, in April one, in May one, in July one, in August one, in September one, in October three and in December three sightings (Table 3). The bottlenose dolphin was mainly observed in groups of two and more individuals (68\% of all sightings, Fig. 3), with the maximum group size $=14$ (Table 2 ). The maximum monthly group size was observed in March (mean=5.5, median=4), and the minimum in July and September (mean=2, median=2; Fig. 2). The annual mean group size was 3.1 (median=2; Table 2).

Short-beaked common dolphins (Delphinus delphis) were recorded all year round except in October (Fig. 2), and constituted $17 \%$ of all sightings. We detected marginally significant difference in the number of sightings among seasons $(\mathrm{p}=0.049)$. The KruskalWallis test showed significant fluctuations in sightings among different times of day $(\mathrm{p}=0.043)$. One calf in May, two calves in June and two calves in July accompanied the adult animals, and one juvenile near an adult was observed in February 2020 (Table 3). In 80\% of sightings the common dolphins were recorded as groups with size greater than 1 (Fig. 3). Groups of size 10 and more were detected in $5 \%$ of observations with the maximum number of individuals equal to 31 (Table 2). The maximum mean group size was recorded in July (12 specimens) with median 8 and the minimum mean group size was recorded in November ( 2 individuals, median=2; Figs 2 and 5). The year average group size was 4.4 ; median $=3$ (Table 2 ). The common dolphins were most frequently observed at a distance of more than $1000 \mathrm{~m}$ from the shore, but in several cases they came within 70 to $100 \mathrm{~m}$.

Table 3. - Number of sightings of young animals during the land-based observations. * Only one category of young animals (calves) was recorded for the harbour porpoise because the remaining age categories are difficult to distinguish reliably from the shore.

\begin{tabular}{|c|c|c|c|c|c|c|}
\hline \multirow[b]{2}{*}{ Season } & \multicolumn{2}{|c|}{ Phocoena phocoena } & \multicolumn{2}{|c|}{ Tursiops truncatus } & \multicolumn{2}{|c|}{ Delphinus delphis } \\
\hline & Calf & Juvenile* & Calf & Juvenile & Calf & Juvenile \\
\hline Winter & 5 & NA & 0 & 3 & 0 & 1 \\
\hline Spring & 4 & NA & 7 & 3 & 1 & 0 \\
\hline Summer & 2 & NA & 3 & 2 & 4 & 0 \\
\hline Autumn & 0 & NA & 0 & 4 & 0 & 0 \\
\hline
\end{tabular}


Table 4. - Non-parametric tests of seasonal variation before and after decomposition of the respective time series. Significant values are in the bold font. SF, sighting frequency; GS, mean group size. * Test performed on the two-year data 2018-19 (24 months); ** Data from JanuaryMay 2020 included.

\begin{tabular}{|c|c|c|c|c|c|c|}
\hline \multirow{2}{*}{ Species } & \multirow[b]{2}{*}{ Test } & \multicolumn{3}{|c|}{ Before decomposition } & \multicolumn{2}{|c|}{ After decomposition } \\
\hline & & Quade * & Friedman * & Friedman $* *$ & Friedman $*$ & Friedman $* *$ \\
\hline \multicolumn{7}{|c|}{ Phocoena phocoena } \\
\hline & SF test statistic & 2.87 & 17.65 & 14.79 & 22 & 25.05 \\
\hline & SF p-value & 0.047 & 0.09 & 0.19 & 0.024 & 0.0077 \\
\hline & GS test statistic & 1.19 & 12.22 & 14.45 & 22 & 25.59 \\
\hline & GS p-value & 0.39 & 0.35 & 0.21 & 0.024 & 0.0074 \\
\hline \multicolumn{7}{|c|}{ Tursiops truncatus } \\
\hline & SF test statistic & 1.18 & 12.12 & 12.06 & 22 & 25.98 \\
\hline & SF p-value & 0.39 & 0.35 & 0.36 & 0.024 & 0.0066 \\
\hline & GS test statistic & 3.20 & 18.19 & 19.67 & 22 & 25.59 \\
\hline \multirow{2}{*}{\multicolumn{7}{|c|}{ Delphinus delphis }} \\
\hline & & & & & & \\
\hline & SF p-value & $\begin{array}{l}1.63 \\
0.21\end{array}$ & $\begin{array}{c}14.29 \\
0.22\end{array}$ & $\begin{array}{l}13.9 \\
0.24\end{array}$ & 0.024 & $\begin{array}{c}25.6 / \\
\mathbf{0 . 0 0 7 3}\end{array}$ \\
\hline & GS test statistic & 2.99 & 17.9 & 13.88 & 22 & 25.59 \\
\hline & GS p-value & 0.04 & 0.08 & 0.24 & 0.024 & 0.0074 \\
\hline
\end{tabular}

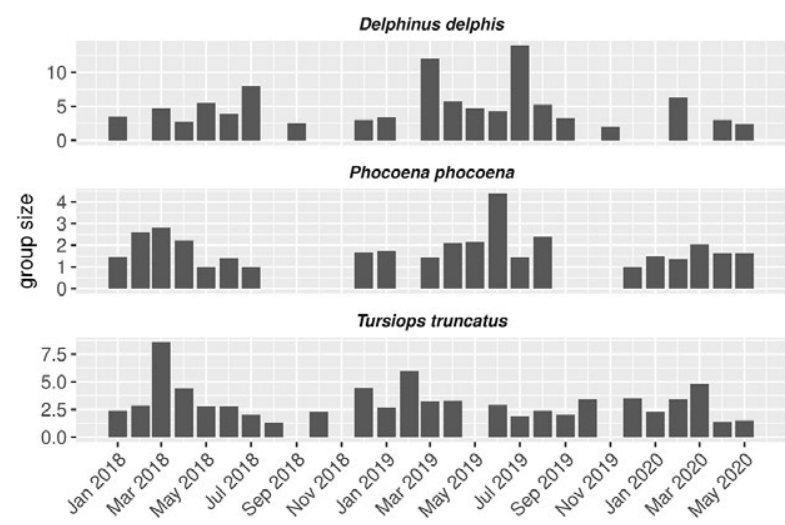

Fig. 5. - Dynamics of mean group size for three cetacean species observed in the study area from January 2018 to May 2020.

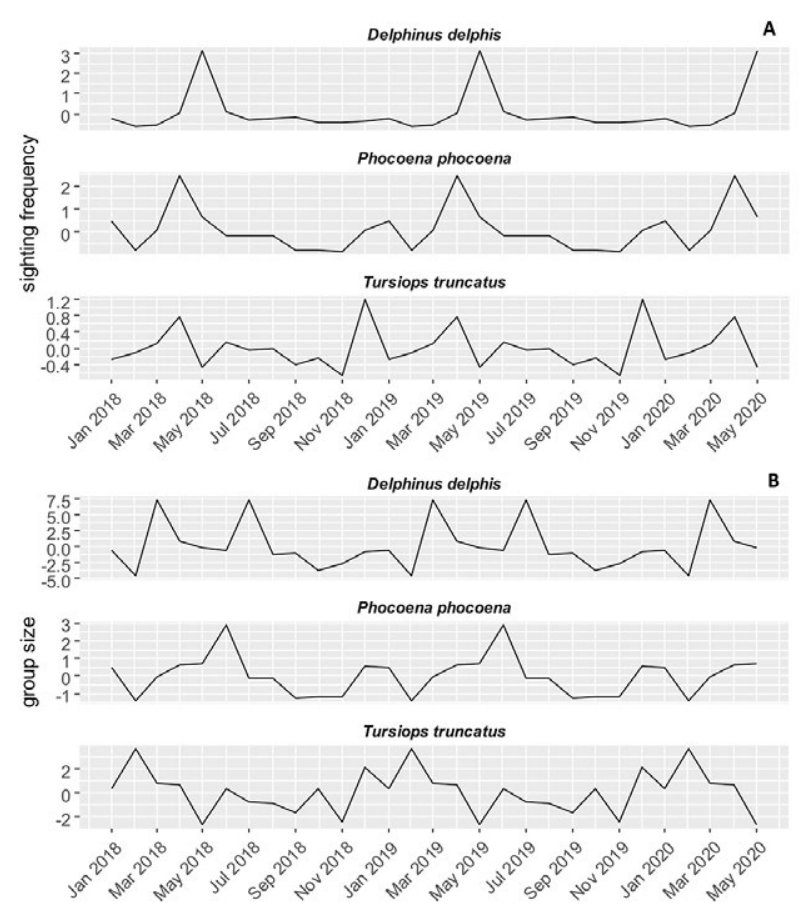

Fig. 6. - The seasonal component of the sighting frequency (A) and the mean group size (B) for the three cetacean species after the respective time series decomposition (January 2018-May 2020).

\section{Time series analysis}

We estimated the amount of seasonal variation in the sighting frequency and the average group size per month using the non-parametric Quade and Friedman rank sum tests (Table 4). When applied to the raw data, the Quade test was only significant in the case of sightings of harbour porpoises and the group size of the bottlenose and common dolphins over a 24-month period ( $p<0.05,2018-2019)$, and the Friedman test was marginally significant only in the case of group size of the bottlenose dolphin over the 29 -month period $(\mathrm{p}=0.05$, January 2018 - May 2020). We then represented the data as time series and used decomposition analysis to remove the yearly trend and error components from the respective time series (R Core Team 2020). This procedure resulted in the Friedman test becoming highly significant in all cases $(\mathrm{p}<0.05)$, regardless of whether 24- or 29-month data were used (Table 4). The similar p-values among different species reflect the respective year-to-year similarities in the sum ranks of the data from 12 discrete months.

The time series seasonal components of both the sighting frequency and the group size over 29 months (Fig. 6A, B) capture most of the temporal dynamics seen in the raw data (see Figs 4 and 5). The SF shows a more or less stable increase during the spring season, followed by a decrease/absence in summer/autumn for all three species. The group size seasonal component shows an increase in the spring-summer period. We found that the error component was low relative to the seasonal and trend components (Supplementary Material, Tables S1, S2).

\section{DISCUSSION}

In this study, we have analysed the seasonal occurrence dynamics and group size of three cetacean species observed locally from the shore in the Zonguldak administrative region in the southwestern part of the Black Sea. We detected seasonal variation in all three species, with the most pronounced seasonal pattern being found in the harbour porpoise, followed by the common dolphin and the bottlenose dolphin. 
Sightings of harbour porpoises in the Zonguldak region contrast with the published data from the coastal waters of Romania and Bulgaria, where this species was most abundant in the summer months (Panayotova and Todorova 2015a, Paiu et al. 2019a). Along the Georgian Black Sea coast, Kopaliani et al. (2015) reported a change in the number of these cetaceans from $\sim 18000$ in winter to 500 in summer. Combined with our results, this supports the earlier suggestion (i) that the southern coastline of the Black Sea is a primary overwintering area for harbour porpoise (BSC 2008). It has also been suggested that (ii) an isolated aggregation of the harbour porpoises exists in the western part of the Black Sea off the coast of Bulgaria and Romania (Mikhalev 2005b), where they spend most time in the summer period and then migrate to the southwestern coastlines of the Black Sea in winter. Further research, in particular photo-identification data, is necessary to confirm our conclusion (i) and/or to test the hypothesis (ii) that the Zonguldak region is used as a transient corridor between the west and east coasts of the Black Sea.

Although the harbour porpoise can occur far offshore ( $>200 \mathrm{~m}$ isobaths), it prefers shallow waters (Mikhalev 2005b, BSC 2008), in agreement with our results. However, sightings of this species might be underestimated, because less favourable weather and sea conditions prevent accurate detection from large distances: these animals have a short dorsal fin and do not emerge prominently from the water surface (Gladilina et al. 2009, Clarke et al. 2017).

Occasional recordings of the harbour porpoise calves in Zonguldak were made throughout the study period. In the coastal waters near the Karadag Nature Reserve in Crimea, the calving season lasts from April to July (Gladilina et al. 2009). In Romanian coastal waters, Paiu et al. (2019a) observed the offspring mostly in the summer. Other authors also consider summer as the calving time for the harbour porpoise in various regions (Learmonth et al. 2014, Vishnyakova and Gol'din 2015). A longer period of calf observations in our region should be a subject of further research.

The increase in the recording of mother-calf units in our study area could at least partly explain a corresponding increase in the group size during the spring season. Such a pattern can be clearly seen in the Atlantic populations of $P$. phocoena (Elliser et al. 2017). Prolonged presence and larger group sizes of this species had only been observed in the summer of 2019 (Figs 4 and 5). We speculate that this might be a once-only event caused by particular environmental conditions.

The short-beaked common dolphins do not have a clear migration pattern but follow seasonal aggregations of preferred prey and form dense concentrations in different regions of the Black Sea (BSC 2008, Birkun et al. 2014). During our land-based observations, we had an opportunity to record only those groups of common dolphins that reached the shallow waters of our study area. They were more frequently observed in the late spring and early summer period. Surveys in deep waters show that this species was abundant along the Turkish coast in April and July (Çelikkale et al. 1989, Uluduz et al. 2019). Dede and Tonay (2010) report- ed that the common dolphin was the most frequently observed species in the western Black Sea during the autumn months. In winter they are abundant near the Georgian coast, with subsequent decrease in number in spring and summer (Kopaliani et al. 2015).

According to the model of Sanchez-Cabanes et al. (2017), the short-beaked common dolphins prefer depths of $>50 \mathrm{~m}$ with low temperatures. In the Black Sea, the coastal areas with greater depths are more suitable for this pelagic species (Gladilina 2012, Panayotova et al. 2017). During the aerial surveys, and partially boat surveys, it was shown that the numbers of common dolphins in the Black Sea increase from west to east (Mikhalev 2008, Paiu et al. 2019b). This variation is, however, unlikely to be caused by any population differentiation because this species is genetically highly uniform across its entire range in the Black Sea (Natoli et al. 2008, Tonay et al. 2020).

Observations of calves of short-beaked common dolphins were made in the summer months. This agrees with historical records from the northern part of the Black Sea, where calving lasts from May till September but peaks in the middle of summer (Kleinenberg 1956). Because we made only a few sightings of young specimens over the study period, a clearer pattern of adult-calf aggregations could not be established.

While the common dolphins tend to occur in the region more often in the warmer season, their group sizes remain relatively stable, varying from 4.3 to 5.5 (with a peak in July). Much larger units of the common dolphin are usually recorded in deeper waters outside the sea shelf zones (Mikhalev 2008), but we are unaware of more precise figures that could be directly compared with our results.

The bottlenose dolphin is not a prevailing cetacean species in the eastern part of the Turkish Black Sea coastline (Çelikkale et al. 1989, Panayotova and Todorova 2015a, Paiu et al. 2019b), but it was regularly encountered in the Zonguldak region (the western coastline) within the study period. Bottlenose dolphins occur in the study area all year around; more often they were recorded in spring and summer, with the number of sightings decreasing in autumn. This decrease might depend on intense marine traffic (Tenan et al. 2020) during the simultaneous fishing season on Atlantic bonito in the region. In contrast, in Ukrainian waters, which are much shallower, the highest number of sightings of bottlenose dolphins was recorded in the autumn period (Mikhalev 2005a).

The reproductive season varies for bottlenose dolphins, but peaks of calving correspond to the period with high water temperature (Würsig 1978). This is in agreement with our data, as calves were observed in spring and early summer. In the northern part of the Black Sea, Gol'din and Gladilina (2015) also documented the peak of the calving season in spring months between the years 2011 and 2014, despite the fact that early spring is the coldest time, with the average water surface temperature of $7^{\circ} \mathrm{C}$ to $8^{\circ} \mathrm{C}$. This disagreement can be explained if some members of the population represent immigrants of Mediterranean origin with early reproductive seasonality (Gol'din and Gladilina 2015). 
In our observations, most bottlenose dolphins were recorded as groups of 2 to 5 individuals. This is consistent with data from other Black Sea regions (Gladilina 2012, Panayotova et al. 2017, Paiu et al. 2019a). However, the maximum group sizes in our records were much higher, i.e. 12 to 14 individuals compared with 7 to 8 along the Bulgarian and Romanian coast, whereas Gladilina et al. (2009) in Ukraine also reported large groups of up to 18 individuals. The absence of natural predators of cetaceans in the Black Sea might suggest that grouping patterns can be influenced by foraging behaviour (Heithaus and Dill 2009) and other factors, which require both data on distribution of cetaceans and actual movement patterns of fishes in the study (Bouveroux et al. 2018). The increase in the group size in spring period might be affected by the forming of "nursery groups" (Kerr et al. 2005, Gibson and Mann 2008, Barker and Berrow 2015), and would correspond to our observations of calves in March to June.

In conclusion, this study contributes to our knowledge of seasonal dynamics of occurrence of all three cetacean species along a previously poorly surveyed part of the Black Sea coast. The sightings and the group size of the harbour porpoise demonstrate the strongest seasonality, with a clear peak in the winter-spring period. We suggest that annual migration is the main factor in these fluctuations. The bottlenose dolphin and the short-beak common dolphin are found in the study area all year round, with some variation across seasons, possibly explained by the respective changes in fish prey availability. The spring and summer periods are important for reproductive activity for all three species of Black Sea cetaceans. In addition, the results presented here emphasize the importance of the coastal waters of the Zonguldak region as an essential habitat for the bottlenose dolphins and harbour porpoises on the southwestern coastline of the Black Sea.

\section{AUTHORS CONTRIBUTION}

All three authors took part in the study design, and MS and AY supervised the study. NU performed fieldwork and analysed the data. NU and AY wrote the paper.

\section{ACKNOWLEDGEMENTS}

We are grateful to Arda Mehmet Tonay for discussion and constructive comments on our results, to two anonymous reviewers for their valuable input, and to Andrés Aravena for translating the abstract into Spanish. Special thanks are due to Pavel Gol'din and Elena Gladilina for consultations on the methodology of shore-based cetacean surveys. This work is part of the PhD thesis by Nastassia Uluduz.

\section{REFERENCES}

Barker J., Berrow S. 2016. Temporal and spatial variation in group size of bottlenose dolphins (Tursiops truncatus) in the Shannon Estuary, Ireland. Biol. Environ. Proc. R. Ir. Acad. 116: 63-70. https://doi.org/10.3318/bioe.2016.5

Baş A.A., Öztürk B., Amaha Öztürk A. 2019. Encounter rate, resi- dency pattern and site fidelity of bottlenose dolphins (Tursiops truncatus) within the Istanbul Strait, Turkey. J. Mar. Biol. Ass. U.K. 99: 1009-1016.

https://doi.org/10.1017/S0025315418000577

Birkun A. A. Jr. 2006. Cetaceans. In: Zaitsev Y.P., Aleksandrov B.G., et a (eds), The North-Western Part of the Black Sea: Biology and Ecology. Naukova Dumka, Kiev, Ukraine, pp. 314332. (In Russian).

Birkun A. Jr., Northridge S.P., Willsteed E.A., et al. 2014. Studies for Carrying Out the Common Fisheries Policy: Adverse Fisheries Impacts on Cetacean Populations in the Black Sea. Final report to the European Commission. Brussels, Belgium, 347 pp.

Bouveroux T.N., Caputo M., Froneman P.W., et al. 2018. Largest reported groups for the Indo-Pacific bottlenose dolphin (Tursiops aduncus) found in Algoa Bay, South Africa: Trends and potential drivers. Mar. Mamm. Sci. 34: 645-665. https://doi.org/10.1111/mms.12471

Black Sea Commission (BSC). 2008. State of the Environment of the Black Sea (2001-2006/7). In: Oğuz T. (ed.), Publications of the Commission on the Protection of the Black Sea Against Pollution (BSC) 2008-3. Istambul, Turkey. 448 pp.

Çelikkale M.S., Karacam H., Düzgünes E., et al. 1989. Size and distribution of dolphin populations in the Black Sea. Turkish. J. Zool. 13: 189- 196.

Clarke R.H., Gales R., Schulz M. 2017. Land-based observations of cetaceans and a review of recent strandings at subantarctic Macquarie Island. Aust. Mammal. 39: 248-253. https://doi.org/10.1071/AM16007

Conover W.J., Iman R.L. 1981. Rank transformations as a bridge between parametric and non-parametric statistics. Am. Stat. 35: 124-129. https://doi.org/10.1080/00031305.1981.10479327

Dede A., Tonay A.M. 2010. Cetacean Sightings in the Western Black Sea in Autumn 2007. J. Environ. Prot. Ecol. 11: 1491-1494.

Dede A., Öztürk A.A., Akamatsu T., et al. 2014. Long-term passive acoustic monitoring revealed seasonal and diel patterns of cetacean presence in the Istanbul Strait. J. Mar. Biol. Ass. U.K. 94: 1195-1202. https://doi.org/10.1017/S0025315413000568

Elliser C.R., MacIver K.H., Green M. 2017. Group characteristics, site fidelity, and photo-identification of harbor porpoises, Phocoena phocoena, in Burrows Pass, Fidalgo Island, Washington. Mar. Mamm. Sci. 34: 365-384. https://doi.org/10.1111/mms.12459

Genov T., Centrih T., Kotnjek P., et al. 2019. Behavioural and temporal partitioning of dolphin social groups in the northern Adriatic Sea. Mar. Biol. 166: 11 https://doi.org/10.1007/s00227-018-3450-8

Gibson Q.A., Mann J. 2008. The size, composition and function of wild bottlenose dolphin (Tursiops sp.) mother-calf groups in Shark Bay, Australia. Anim. Behav. 76: 389-405. https://doi.org/10.1016/j.anbehav.2008.01.022

Gladilina E.V. 2012. Observations of Cetaceans (Cetacea) in the waters of Karadag nature reserve and the adjacent waters. Scientific Notes TNU. Series "Biology, Chemistry" 25: 51-59. (In Russian).

Gladilina E.V., Gol'din P.E. 2014. New prey fishes in diet of Black Sea bottlenose dolphin (Mammalia, Cetacea). Vestn. Zool. 48: 83-92. https://doi.org/10.2478/vzoo-2014-0009

Gladilina E.V. Gol'din PE. 2016. Abundance and Summer Distribution of a Local Stock of Black Sea Bottlenose dolphins, Tursiops truncatus (Cetacea, Delphinidae), in Coastal Waters near Sudak (Ukraina, Crimea). Vestn. Zool. 50: 49-56. https://doi.org/10.1515/vzoo-2016-0006

Gladilina E.V., Kukushkin O.V., Gol'din P.E. 2009. Current status of cetaceans in the waters of Karadag Natural Reserve. In: Gaevskaya A.V., Morozova A.L. (eds), Collection of scientific papers dedicated to the 95th anniversary of the Karadag scientific station and the 30th anniversary of Karadag Nature Reserve NAS Ukraine. ECOSY-Gidrofizika, Sevastopol, pp. 407-412.

Gladilina E.V., Lyashenko Y.N., Gol'din P.E. 2013. Winter distribution of cetaceans in the Black Sea and adjoining areas in 2012/2013. Scientific Notes TNU. Series "Biology, Chemistry" 26: $37-42$.

Gol'din P., Gladilina E. 2015. Small dolphins in a small sea: age, growth and life-history aspects of the Black Sea common bottlenose dolphin Tursiops truncatus. Aquat. Biol. 23: 159-166. https://doi.org/10.3354/ab00617

Hammond P.S., Bearzi G., Bjørge A., et al. 2008. Delphinus delphis. In: IUCN 2020. IUCN Red List of Threatened Species. 
Version 2020.1. Downloaded on 23 May 2020. http://www.iucnredlist.org

Heithaus M.R., Dill L. 2009. Feeding strategies and tactics. In: Perrin W.F., Wursig B., et al. (eds), The encyclopedia of marine mammals, 2nd edition. Academic Press, San Diego, California, pp. 414-423. https://doi.org/10.1016/B978-0-12-373553-9.00099-7

Ivanov V.A., Belokopytov V.N. 2013. Oceanography of the Black Sea. National Academy of Science of Ukraine, Marine Hydrophysical Institute, Sevastopol, $210 \mathrm{pp}$.

Kerr K., Defran R., Campbell G. 2005. Bottlenose Dolphins (Tursiops truncatus) in the Drowned Cayes, Belize: Group Size, Site Fidelity and Abundance. Caribb. J. Sci. 41: 172-177.

Kleinenberg S.E. 1956. Mammals of the Black Sea and the Sea of Azov: an Experience of Biological and Fisheries Research. USSR Acad. Science Publ. House, Moscow, 290 pp. (In Russian).

Kopaliani N., Gurielidze Z., Devidze N., et al. 2015. Monitoring of Black Sea Cetacean in Georgian Waters. Accessed on 17 May 2020 at https://chm.cbd.int/database/record?documentID $=241761$

Latif M.A., Özsoy E., Oğuz T., et al. 1991. Observations of the Mediterranean inflow into the Black Sea. Deep Sea Res. 38: 711-723. https://doi.org/10.1016/S0198-0149(10)80005-6

Learmonth J.A., Murphy S., Luque P.L., et al. 2014. Life history of harbor porpoises (Phocoena phocoena) in Scottish (UK) waters. Mar. Mamm. Sci. 30: 1427-1455. https://doi.org/10.1111/mms.12130

Marini C., Fossa F., Paoli C., et al. 2015. Predicting bottlenose dolphin distribution along Liguria coast (Northwestern Mediterranean Sea) through different modeling techniques and indirect predictors. J. Environ. Manage. 150: 9-20. https://doi.org/10.1016/j.jenvman.2014.11.008

Mikhalev Y.A. 2005a. The Peculiarities of the Distribution of Bottlenose Dolphin Tursiops truncatus (Cetacea) in the Black Sea. Vestn. Zool. 39: 29-42.

Mikhalev Y.A. 2005b. The Peculiarities of the Distribution of the Harbour Porpoise Phocoena phocoena relicta (Cetacea) in the Black Sea. Vestn. Zool. 39: 25-35.

Mikhalev Y.A. 2008. Results of observations on distribution of common dolphins in the Black Sea. In: Marine Mammals of the Holartic. Collection of Scientific Papers. Odessa, Ukraine, pp. 364-368

Natoli A., Canadas A., Vaquero C., et al. 2008. Conservation genetics of the short-beaked common dolphin (Delphinus delphis) in the Mediterranean Sea and in the eastern North Atlantic Ocean. Conserv. Genet. 9: 1479-1487. https://doi.org/10.1007/s10592-007-9481-1

Oğuz T. 2005. Hydraulic adjustments of the Bosphorus Exchange flow. Geophys. Res. Lett. 32: L06604. https://doi.org/10.1029/2005GL022353

Paiu R.M., Olariu B., Paiu A.I., et al. 2019a. Cetaceans in the coastal waters of southern Romania: initial assessment of abundance, distribution, and seasonal trends. J. Black Sea/Medit. Environ. 25: 266-279.

Paiu R.M., Mirea-Candea M., Belmont J., et al. 2019b. CeNoBS - a step closer in completing a generation dream: Basin-wide survey of cetaceans in ACCOBAMS area. In: World Marine Mammals conference. Book of Abstracts. International Barcelona Convention Center, Barcelona, Spain, pp. 611-612.

Panayotova M., Todorova V. 2015a. Distribution of three cetacean species along the Bulgarian Black Sea coast in 2006-2013. J. Black Sea/Medit. Environ. 21: 45-53.

Panayotova M.D., Todorova V.R. 2015b. Using Opportunistic Sightings to Assess the Distribution of Small Cetaceans in Bulgarian Waters of the Black Sea in 2012. Acta Zool. Bulg. 67: 421-427.

Panayotova M., Marinova V., Slavova K., et al. 2017. Studying of the distribution and abundance of marine mammals in the Bulgarian Black Sea area by combination of visual and acoustic observations. Proc. Inst. Fish. Resour. 28: 34-40.

R Core Team. 2020. R: A language and environment for statistical computing. R Foundation for Statistical Computing. Vienna,
Austria.

http://www.R-project.org

Reeves R., Notarbartolo di Sciara G. 2006. The status and distribution of cetaceans in the Black Sea and Mediterranean Sea. IUCN Centre for Mediterranean Cooperation, Malaga, Spain, $137 \mathrm{pp}$.

Rogan E., Ingram S., Holmes B., et al. 2000. A survey of bottlenose dolphins (Tursiops truncatus) in the Shannon estuary. Mar. Resour. Ser. 9: 1-46.

Ryakov V., Panayotova M. 2012. Cetacean sightings of the Bulgarian Black Sea coast over the period 2006-2010. J. Environ. Prot. Ecol. 13: 1824-1835.

Sanchez-Cabanes A., Nimak-Wood M., Harris N., et al. 2017. Habitat preferences about three top predators inhabiting a degraded ecosystem, the Black Sea. Sci. Mar. 81: 217-227. https://doi.org/10.3989/scimar.04493.07A

Tenan S., Hernández N., Fearnbach H., et al. 2020. Impact of maritime traffic and whale-watching on apparent survival of bottlenose dolphins in the Strait of Gibraltar. Aquat. Conserv. 30: 949-958. https://doi.org/10.1002/aqc.3292

Tezcan D., Yücel M., Ciftci G. 2017. Geology and geophysics of the southern shelf of the Black Sea. In: Sezgin M., Bat L., et al. (eds), Sea Marine Environment: The Turkish Shelf. Turkish Marine Research Foundation, İstambul, Turkey, pp. 32-51.

Tonay A., Öztürk A.A. 2012. Historical records of cetacean fishery in the Turkish seas. J. Black Sea/Medit. Environ. 18: 388-399.

Tonay A.M., Uzun B., Dede A., et al. 2020. Population genetic structure of the short-beaked common dolphin from the Black Sea and the Turkish Straits System. Mitochondrial DNA Part A $31: 257-264$. https://doi.org/10.1080/24701394.2020.1788008

Uluduz N., Gladilina E., Yanchukov A., et al. 2019. Primary abundance estimation of the Black Sea cetaceans in the adjacent waters of Zonguldak, Turkey. In: EEBST 2019. Ecology and Evolutionary Biology Symposium. Abstract Book. Ankara, Turkey, pp. 44.

Viaud-Martinez K.A., Milmer M.V., Gol'din P.E., et al. 2007. Morphological and genetic differentiation of the Black Sea harbour porpoise Phocoena phocoena. Mar. Ecol. Prog. Ser. 338: 281-294 https://doi.org/10.3354/meps338281

Viaud-Martinez K.A., Brownell R.L. Jr. Komnenouc A, et al. 2008. Genetic isolation and morphological divergence of Black Sea bottlenose dolphins. Biol. Conserv. 141: 1600-1611 https://doi.org/10.1016/j.biocon.2008.04.004

Vishnyakova K., Gol'din P. 2015. Seasonality of strandings and bycatch of harbour porpoises in the Sea of Azov: the effects of fisheries, weather conditions, and life history. ICES J. Mar. Sci. 72: 981-991. https://doi.org/10.1093/icesjms/fsu192

Wittkowski K.M., Song T. 2012. MuStat: Prentice Rank Sum Test and McNemar Test. R package version 1.7.0. Downloaded on 15 May 2020 http://www.CRAN.R-project.org/package=muStat

Würsig B. 1978. Occurrence and group organization of Atlantic bottlenose porpoises (Tursiops truncatus) in an Argentine bay. Biol. Bull. 154: 348-359. https://doi.org/10.2307/1541132

Zaitsev Y. 2008. An Introduction to the Black Sea Ecology. Smil Ed. Publ. Agency Ltd., Odessa, 228 pp.

\section{SUPPLEMENTARY MATERIAL}

The following supplementary material is available through the online version of this article and at the following link:

http://scimar.icm.csic.es/scimar/supplm/sm05086esm.pdf

Table S1. - Decomposition of the sighting frequency time series into three components.

Table S2. - Decomposition of the group size time series into three components. 
Seasonal dynamics of occurrence and group size of three species of cetaceans (Delphinidae and Phocoenidae) on the southwestern coast of the Black Sea

Nastassia Uluduz, Alexey Yanchukov, Mustafa Sözen

Supplementary material 
Table S1. Decomposition of the sighting frequency time series into three components

\begin{tabular}{|c|c|c|c|c|}
\hline Year/month & Observed & Seasonal component & Trend & Random error \\
\hline \multicolumn{5}{|c|}{$\begin{array}{l}\text { Tursiops truncatus } \\
2018\end{array}$} \\
\hline January & 0.38 & -0.27968750 & NA & NA \\
\hline February & 1.50 & -0.12760417 & NA & NA \\
\hline March & 0.50 & 0.12281250 & NA & NA \\
\hline April & 1.19 & 0.78531250 & NA & NA \\
\hline May & 0.83 & -0.48385417 & NA & NA \\
\hline June & 0.50 & 0.16072917 & NA & NA \\
\hline July & 0.39 & -0.03427083 & 0.6183333 & -0.194062500 \\
\hline August & 0.25 & -0.01093750 & 0.5733333 & -0.312395833 \\
\hline September & 0.00 & -0.41927083 & 0.5441667 & -0.124895833 \\
\hline October & 0.17 & -0.24364583 & 0.5695833 & -0.155937500 \\
\hline November & 0.00 & -0.67031250 & 0.5583333 & 0.111979167 \\
\hline December & 1.75 & 1.20072917 & 0.5479167 & 0.001354167 \\
\hline \multicolumn{5}{|l|}{2019} \\
\hline January & 0.30 & -0.27968750 & 0.5783333 & 0.001354167 \\
\hline February & 0.50 & -0.12760417 & 0.6262500 & 0.001354167 \\
\hline March & 0.80 & 0.12281250 & 0.6758333 & 0.001354167 \\
\hline April & 1.50 & 0.78531250 & 0.7133333 & 0.001354167 \\
\hline May & 0.25 & -0.48385417 & 0.7325000 & 0.001354167 \\
\hline June & 0.83 & 0.16072917 & 0.6679167 & 0.00134167 \\
\hline July & 0.79 & -0.03427083 & 0.6275000 & 0.196770833 \\
\hline August & 1.00 & -0.01093750 & 0.6958333 & 0.315104167 \\
\hline September & 0.44 & -0.41927083 & 0.7316667 & 0.127604167 \\
\hline October & 0.63 & -0.24364583 & 0.7150000 & 0.158645833 \\
\hline November & 0.00 & -0.67031250 & 0.7795833 & -0.109270833 \\
\hline \multirow{2}{*}{\multicolumn{5}{|c|}{2020}} \\
\hline & & & & \\
\hline January & 0.88 & -0.27968750 & NA & NA \\
\hline February & 1.56 & -0.12760417 & NA & NA \\
\hline March & 0.60 & 0.12281250 & NA & NA \\
\hline April & 1.30 & 0.78531250 & NA & NA \\
\hline May & 2.00 & -0.48385417 & NA & NA \\
\hline \multicolumn{5}{|c|}{ Phocoena phocoena } \\
\hline January & 0.50 & 0.46381944 & NA & NA \\
\hline February & 0.30 & -0.80826389 & NA & NA \\
\hline March & 0.79 & 0.05006944 & NA & NA \\
\hline April & 1.94 & 2.48006944 & NA & NA \\
\hline May & 0.50 & 0.65006944 & NA & NA \\
\hline June & 0.21 & -0.15284722 & NA & NA \\
\hline July & 0.06 & -0.18180556 & 0.4500000 & 0.208194444 \\
\hline August & 0.00 & -0.16555556 & 0.4666667 & -0.301111111 \\
\hline September & 0.00 & -0.77222222 & 0.4587500 & 0.313472222 \\
\hline October & 0.00 & -0.79868056 & 0.5212500 & 0.277430556 \\
\hline November & 0.00 & -0.82805556 & 0.6208333 & 0.207222222 \\
\hline December & 0.75 & 0.06340278 & 0.6816667 & 0.004930556 \\
\hline \multicolumn{5}{|l|}{2019} \\
\hline January & 1.20 & 0.46381944 & 0.7312500 & 0.004930556 \\
\hline February & 0.00 & -0.80826389 & 0.8033333 & 0.004930556 \\
\hline March & 0.90 & 0.05006944 & 0.8450000 & 0.004930556 \\
\hline April & 3.33 & 2.48006944 & 0.8450000 & 0.004930556 \\
\hline May & 1.50 & 0.65006944 & 0.8450000 & 0.004930556 \\
\hline June & 0.67 & -0.15284722 & 0.8179167 & 0.004930556 \\
\hline July & 0.79 & -0.18180556 & 0.7537500 & 0.218055556 \\
\hline August & 1.00 & -0.16555556 & 0.8545833 & 0.310972222 \\
\hline September & 0.00 & -0.77222222 & 1.0758333 & -0.303611111 \\
\hline October & 0.00 & -0.79868056 & 1.0662500 & -0.267569444 \\
\hline November & 0.00 & -0.82805556 & 1.0254167 & -0.197361111 \\
\hline December & 0.10 & 0.06340278 & NA & NA \\
\hline \multicolumn{5}{|l|}{2020} \\
\hline January & 0.31 & 0.46381944 & NA & NA \\
\hline February & 3.31 & -0.80826389 & NA & NA \\
\hline March & 2.90 & 0.05006944 & NA & NA \\
\hline April & 1.10 & 2.48006944 & NA & NA \\
\hline May & 2.75 & 0.65006944 & NA & NA \\
\hline \multicolumn{5}{|c|}{ Delphinus delphis } \\
\hline \multicolumn{5}{|l|}{2018} \\
\hline January & 0.08 & 0.25097222 & NA & NA \\
\hline February & 0.00 & -0.62097222 & NA & NA \\
\hline March & 0.21 & -0.53763889 & NA & NA \\
\hline April & 0.25 & 0.03236111 & NA & NA \\
\hline May & 0.17 & 3.12069444 & NA & NA \\
\hline June & 0.29 & 0.13944444 & NA & NA \\
\hline July & 0.06 & -0.30472222 & 0.1579167 & 0.20680556 \\
\hline
\end{tabular}




\begin{tabular}{|c|c|c|c|c|}
\hline Year/month & Observed & Seasonal component & Trend & Random error \\
\hline August & 0.00 & -0.21993056 & 0.1691667 & 0.05076389 \\
\hline September & 0.25 & -0.18243056 & 0.1645833 & 0.26784722 \\
\hline October & 0.00 & -0.42493056 & 0.1775000 & 0.24743056 \\
\hline November & 0.20 & -0.42243056 & 0.3441667 & 0.27826389 \\
\hline $\begin{array}{l}\text { December } \\
2019\end{array}$ & 0.25 & -0.32847222 & 0.5125000 & 0.06597222 \\
\hline January & 0.35 & 0.25097222 & 0.5350000 & 0.06597222 \\
\hline February & 0.00 & -0.62097222 & 0.5550000 & 0.06597222 \\
\hline March & 0.10 & -0.53763889 & 0.5716667 & 0.06597222 \\
\hline April & 0.67 & 0.03236111 & 0.5716667 & 0.06597222 \\
\hline May & 3.75 & 3.12069444 & 0.5633333 & 0.06597222 \\
\hline June & 0.75 & 0.13944444 & 0.5445833 & 0.06597222 \\
\hline July & 0.14 & -0.30472222 & 0.5195833 & -0.07486111 \\
\hline August & 0.40 & -0.21993056 & 0.5387500 & 0.08118056 \\
\hline September & 0.25 & -0.18243056 & 0.5683333 & -0.13590278 \\
\hline October & 0.00 & -0.42493056 & 0.5404167 & -0.11548611 \\
\hline November & 0.00 & -0.42243056 & 0.5687500 & -0.14631944 \\
\hline December & 0.00 & -0.32847222 & NA & NA \\
\hline \multicolumn{5}{|l|}{2020} \\
\hline January & 0.00 & 0.25097222 & NA & NA \\
\hline February & 0.81 & -0.62097222 & NA & NA \\
\hline March & 0.00 & -0.53763889 & NA & NA \\
\hline April & 0.10 & 0.03236111 & NA & NA \\
\hline May & 5.00 & 3.12069444 & NA & NA \\
\hline
\end{tabular}

Mean seasonal effects (\$figure) extracted from the sighting frequency time series

Tursiops truncatus

Sfigure

$\left[\begin{array}{lllllll}{[1]} & -0.27968750 & -0.12760417 & 0.12281250 & 0.78531250 & -0.48385417 & 0.16072917\end{array}\right.$

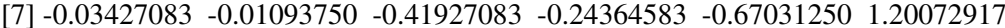

Phocoena phocoena

Sfigure

[1] $0.46381944 \quad-0.808263890 .050069442 .480069440 .65006944-0.15284722$

$\left[\begin{array}{lllllll}{[7]} & -0.18180556 & -0.16555556 & -0.77222222 & -0.79868056 & -0.82805556 & 0.06340278\end{array}\right.$

Delphinus delphis

\$figure

[1] $-0.25097222 \quad-0.62097222 \quad-0.537638890 .03236111 \quad 3.120694440 .13944444$

$[7]-0.30472222 \quad-0.21993056 \quad-0.18243056 \quad-0.42493056-0.42243056-0.32847222$ 
Table S2. Decomposition of the group size time series into three components.

\begin{tabular}{|c|c|c|c|c|}
\hline Year/month & Observed & Seasonal component & Trend & Random error \\
\hline \multicolumn{5}{|c|}{$\begin{array}{l}\text { Tursiops truncatus } \\
2018\end{array}$} \\
\hline January & 2.40 & 0.3609028 & NA & NA \\
\hline February & 2.86 & 3.6492361 & NA & NA \\
\hline March & 8.60 & 0.7700694 & NA & NA \\
\hline April & 4.40 & 0.6909028 & NA & NA \\
\hline May & 2.80 & -2.6549306 & NA & NA \\
\hline June & 2.80 & 0.2838194 & NA & NA \\
\hline July & 2.00 & -0.7324306 & 2.835417 & -0.102986111 \\
\hline August & 1.30 & -0.8415972 & 2.977500 & -0.835902778 \\
\hline September & 0.00 & -1.6236806 & 2.885417 & -1.261736111 \\
\hline October & 2.30 & 0.3684028 & 2.616667 & -0.685069444 \\
\hline November & 0.00 & -2.3915972 & 2.454167 & -0.062569444 \\
\hline December & 4.43 & 2.1209028 & 2.341667 & -0.032569444 \\
\hline \multicolumn{5}{|l|}{2019} \\
\hline January & 2.67 & 0.3609028 & 2.341667 & -0.032569444 \\
\hline February & 6.00 & 3.6492361 & 2.383333 & -0.032569444 \\
\hline March & 3.25 & 0.7700694 & 2.512500 & -0.032569444 \\
\hline April & 3.30 & 0.6909028 & 2.641667 & -0.032569444 \\
\hline May & 0.00 & -2.6549306 & 2.687500 & -0.032569444 \\
\hline June & 2.90 & 0.2838194 & 2.648750 & -0.032569444 \\
\hline July & 1.90 & -0.7324306 & 2.594583 & 0.037847222 \\
\hline August & 2.40 & -0.8415972 & 2.470833 & 0.770763889 \\
\hline September & 2.00 & -1.6236806 & 2.427083 & 1.196597222 \\
\hline October & 3.40 & 0.3684028 & 2.411667 & 0.619930556 \\
\hline November & 0.00 & -2.3915972 & 2.394167 & -0.002569444 \\
\hline \multirow{2}{*}{\multicolumn{5}{|c|}{$\begin{array}{l}\text { December } \\
2020\end{array}$}} \\
\hline & & & & \\
\hline January & 2.30 & 0.3609028 & NA & NA \\
\hline February & 3.40 & 3.6492361 & NA & NA \\
\hline March & 4.80 & 0.7700694 & NA & NA \\
\hline April & 1.38 & 0.6909028 & NA & NA \\
\hline May & 1.50 & -2.6549306 & NA & NA \\
\hline \multicolumn{5}{|c|}{ Phocoena phocoena } \\
\hline \multicolumn{5}{|l|}{2018} \\
\hline January & 1.46 & 0.49243056 & NA & NA \\
\hline February & 2.60 & -1.37631944 & NA & NA \\
\hline March & 2.81 & -0.03631944 & NA & NA \\
\hline April & 2.23 & 0.62368056 & NA & NA \\
\hline May & 1.00 & 0.68368056 & NA & NA \\
\hline June & 1.40 & 2.93159722 & NA & NA \\
\hline July & 1.00 & -0.09173611 & 1.1929167 & -0.10118056 \\
\hline August & 0.00 & -0.09152778 & 1.0966667 & -1.00513889 \\
\hline September & 0.00 & -1.24923611 & 0.9312500 & 0.31798611 \\
\hline October & 0.00 & -1.22048611 & 0.8687500 & 0.35173611 \\
\hline November & 0.00 & -1.22111111 & 0.9116667 & 0.30944444 \\
\hline December & 1.67 & 0.55534722 & 1.0841667 & 0.03048611 \\
\hline \multicolumn{5}{|l|}{2019} \\
\hline January & 1.75 & 0.49243056 & 1.2270833 & 0.03048611 \\
\hline February & 0.00 & -1.37631944 & 1.3458333 & 0.03048611 \\
\hline March & 1.44 & -0.03631944 & 1.4458333 & 0.03048611 \\
\hline April & 2.10 & 0.62368056 & 1.4458333 & 0.03048611 \\
\hline May & 2.16 & 0.68368056 & 1.4458333 & 0.03048611 \\
\hline June & 4.38 & 2.93159722 & 1.4179167 & 0.03048611 \\
\hline July & 1.45 & -0.09173611 & 1.3795833 & 0.16215278 \\
\hline August & 2.40 & -0.09152778 & 1.4254167 & 1.06611111 \\
\hline September & 0.00 & -1.24923611 & 1.5062500 & -0.25701389 \\
\hline October & 0.00 & -1.22048611 & 1.5112500 & -0.29076389 \\
\hline November & 0.00 & -1.22111111 & 1.4695833 & -0.24847222 \\
\hline \multirow{2}{*}{\multicolumn{5}{|c|}{2020}} \\
\hline & & & & \\
\hline January & 1.50 & 0.49243056 & NA & NA \\
\hline February & 1.35 & -1.37631944 & NA & NA \\
\hline March & 2.03 & -0.03631944 & NA & NA \\
\hline April & 1.63 & 0.62368056 & NA & NA \\
\hline May & 1.63 & 0.68368056 & NA & NA \\
\hline \multicolumn{5}{|c|}{ Delphinus delphis } \\
\hline January & 3.50 & -0.6534375 & NA & NA \\
\hline February & 0.00 & -4.5221875 & NA & NA \\
\hline March & 4.70 & 7.2278125 & NA & NA \\
\hline April & 2.75 & 0.9465625 & NA & NA \\
\hline May & 5.50 & -0.1867708 & NA & NA \\
\hline June & 3.86 & -0.5451042 & NA & NA \\
\hline July & $\begin{array}{l}3.00 \\
8.00\end{array}$ & 7.2211458 & 2.813333 & -2.0344792 \\
\hline
\end{tabular}




\begin{tabular}{|c|c|c|c|c|}
\hline Year/month & Observed & Seasonal component & Trend & Random error \\
\hline August & 0.00 & -1.2121875 & 2.809167 & -1.5969792 \\
\hline September & 2.50 & -0.9955208 & 3.113333 & 0.3821875 \\
\hline October & 0.00 & -3.7778125 & 3.542500 & 0.2353125 \\
\hline November & 0.00 & -2.7173958 & 3.634167 & -0.9167708 \\
\hline $\begin{array}{l}\text { December } \\
\mathbf{2 0 1 9}\end{array}$ & 3.00 & -0.7851042 & 3.619167 & 0.1659375 \\
\hline January & 3.40 & -0.6534375 & 3.887500 & 0.1659375 \\
\hline February & 0.00 & -4.5221875 & 4.356250 & 0.1659375 \\
\hline March & 12.00 & 7.2278125 & 4.606250 & 0.1659375 \\
\hline April & 5.75 & 0.9465625 & 4.637500 & 0.1659375 \\
\hline May & 4.70 & -0.1867708 & 4.720833 & 0.1659375 \\
\hline June & 4.30 & -0.5451042 & 4.679167 & 0.1659375 \\
\hline July & 14.00 & 7.2211458 & 4.412500 & 2.3663542 \\
\hline August & 5.25 & -1.2121875 & 4.533333 & 1.9288542 \\
\hline September & 3.25 & -0.9955208 & 4.295833 & -0.0503125 \\
\hline October & 0.00 & -3.7778125 & 3.681250 & 0.0965625 \\
\hline November & 2.00 & -2.7173958 & 3.468750 & 1.2486458 \\
\hline December & 0.00 & -0.7851042 & NA & NA \\
\hline \multicolumn{5}{|l|}{2020} \\
\hline January & 0.00 & -0.6534375 & NA & NA \\
\hline February & 6.30 & -4.5221875 & NA & NA \\
\hline March & 0.00 & 7.2278125 & NA & NA \\
\hline April & 3.00 & 0.9465625 & NA & NA \\
\hline May & 2.35 & -0.1867708 & NA & NA \\
\hline
\end{tabular}

Mean seasonal effects (\$figure) extracted from the group size time series

Tursiops truncatus

\$figure

$\left[\begin{array}{llllllll} & 0.3609028 & 3.6492361 & 0.7700694 & 0.6909028 & -2.6549306 & 0.2838194 & -0.7324306\end{array}\right.$

[8] $-0.8415972 \quad-1.6236806 \quad 0.3684028 \quad-2.3915972 \quad 2.1209028$

Phocoena phocoena

\$figure

[1] $0.49243056-1.37631944-0.036319440 .62368056 \quad 0.683680562 .93159722$

[7] $-0.09173611-0.09152778-1.24923611 \quad-1.22048611-1.221111110 .55534722$

Delphinus delphis

\$figure

[1] $-0.6534375-4.5221875 \quad 7.2278125 \quad 0.9465625 \quad-0.1867708 \quad-0.5451042 \quad 7.2211458$

[8] $-1.2121875-0.9955208-3.7778125 \quad-2.7173958-0.7851042$ 